\title{
Exogenous leptin influences gastrointestinal growth and in vitro small intestinal motility in neonatal piglets - preliminary results
}

\author{
J. Woliński ${ }^{1}$, V. Leśniewska ${ }^{2}$, M. Biernat ${ }^{3}$, M. Bąbelewska ${ }^{1}$, \\ W. Korczyński ${ }^{1}$ and R. Zabielski ${ }^{1}$
}

\author{
'The Kielanowski Institute of Animal Physiology and Nutrition, \\ Polish Academy of Sciences \\ 05-110 Jablonna, Poland \\ ${ }^{2}$ Physiology Division, \\ ${ }^{3}$ Department of Anatomy, Histology and Embryology, \\ Warsaw Agricultural University, Faculty of Veterinary Medicine \\ Nowoursynowska 166, 02-787 Warszawa, Poland
}

\begin{abstract}
Eight newborn piglets were randomly assigned to two groups. All of the piglets were fed with a milk replacer using an "artificial sow". Three times daily for six days they received physiological saline $(0.9 \% \mathrm{NaCl})$ (control group, $\mathrm{n}=5$ ) or leptin at $10 \mu \mathrm{g} / \mathrm{kg}$ body weight dissolved in physiological saline (experimental group, $\mathrm{n}=3$ ) administered intragastrically. The piglets were then anaethesized, the entire gastrointestinal tract removed, and fragments of the duodenum and mid-jejunum were harvested and their in vitro motility was measured. Despite lack of differences in body weight, the piglets treated with leptin showed differences in the weight of the stomach and pancreas and length of the ileum in comparison with the controls. Administration of leptin also significantly affected intestinal motility in a manner characteristic of the particular segments $(\mathrm{P}<0.05 ; \mathrm{P}<0.01 ; \mathrm{P}<0.001$, respectively). The spontaneous contractions of the duodenum and its response to acetylcholine and isoproterenol were higher in the group of piglets treated with leptin than in controls, whereas segments of the jejunum behaved in the opposite manner. The experiments will be continued in order to confirm these results on a larger number of animals.
\end{abstract}

KEY WORDS: contractile activity, duodenum, acetylcholine, development, piglets

\section{INTRODUCTION}

Leptin is a 167 -amino acid protein, produced and secreted by adipose tissue, muscles and the reproductive tract. It is involved in the regulation of adipose tissue mass, food intake and body weight in neonatal and adult animals (Frederich et al., 
1995; Masuzaki et al., 1997). Recently it has been shown that leptin is produced by the chief cells in the stomach mucosa (Bado et al., 1998), and that leptin receptors are widely distributed in the gastrointestinal tract, in particular in the stomach and small intestine (Morton et al., 1998). Moreover, it has also been demonstrated that leptin is produced in the mammary gland and secreted into colostrum and milk (Casabiell et al., 1997; Smith-Kirwin et al., 1998; Aoki et al., 1999; Brogan et al., 1999). The above can suggest that milk leptin can play a role in the development of the gastrointestinal tract in neonates. Since gastrointestinal motility is one of basic physiological functions directly responsible for digestion in neonatal pigs and calves (Zabielski and Naruse, 1999; Leśniewska et al., 2000).

The purpose of our study was to investigate the role of exogenous leptin on gastrointestinal tract growth and small intestinal motility in neonatal piglets.

\section{MATERIAL AND METHODS}

Eight male neonatal piglets from 4 different litters in two experimental trials were purchased from a commercial pig farm. Each piglet was kept with its sow for $24 \mathrm{~h}$ after birth, and then transported to the laboratory. At the beginning of each trial, 4 piglets were kept together in one cage for approximately $12 \mathrm{~h}$ of adaptation. After the adaptation period, the piglets were placed in individual cages that provided social contact with other piglets. The animals were housed under a $12 / 12 \mathrm{~h}$ light/dark cycle and ambient temperature that decreased from 32 to $28^{\circ} \mathrm{C}$ during 6 days of the experiment to ensure a comfortable environment for the piglets.

Milk replacer formula for piglets (\%: protein, 19.8; fat, 19.7; ash, 8.2; Milky Farm, Nukamel Olen, Belgium) was distributed to each piglet in equal amounts by means of an Artificial Sow (Research Center Foulum-model, Pig's oline, Boss' Produkter a/s, Denmark) according to an original method established by Leśniewska and Hedemann (unpublished) with our own further modifications. Body weight was measured every morning. All piglets were fed with milk replacer every $75 \mathrm{~min}$ (20 times per $24 \mathrm{~h}$ ). Piglets were randomly divided into 2 groups: control group $(\mathrm{n}=5)$ and leptin group $(\mathrm{n}=3)$. Every $8 \mathrm{~h}$ the piglets received either $5 \mathrm{ml} 0.9 \% \mathrm{NaCl}$ (control group) or the same volume of $\mathrm{NaCl}$ containing leptin (Leptin Mouse Recombinant, Sigma, USA) via a stomach tube at a dose of $10 \mu \mathrm{g} / \mathrm{kg}$ of body weight (leptin group).

After six days of leptin or vehicle treatment, the animals were sacrificed by an overdose of pentobarbiturate (Vetbutal, Biowet, Poland), and the entire gastrointestinal tract was removed for morphometric analysis and tissue sampling. The stomach and pancreas were weighed. The duodenum and mid-jejunum were immediately harvested and put into a $+4^{\circ} \mathrm{C}$ Krebs-Henseleit $(\mathrm{NaCl} 118.0 \mathrm{mM}, \mathrm{KCl}$ $4.7 \mathrm{mM}, \mathrm{CaCl}_{2} 2.5 \mathrm{mM}, \mathrm{MgSO}_{4} 1.6 \mathrm{mM}, \mathrm{NaHCO}_{3} 24.3 \mathrm{mM}, \mathrm{KH}_{2} \mathrm{PO}_{4} 1.18 \mathrm{mM}$, 
glucose $5.6 \mathrm{mM}$ ) solution for $2 \mathrm{~h}$ incubation. After that, $2 \mathrm{~cm}$ whole thickness duodenal and mid-jejunum segments were mounted in an 4-channel automatic organ bath equipped with isotonic pressure transducers (Letica Scientific Instruments, Spain) and coupled to an acquisition data system (PowerLab/4e, ADInstruments, Australia) and PC computer for measuring smooth muscle isotonic contraction activity. During the first hour the intestinal segments were allowed to equilibrate in the Krebs-Henseleit buffer at $37^{\circ} \mathrm{C}$, aerated with carbogen gas $\left(95 \% \mathrm{O}_{2}\right.$ and $5 \%$ $\mathrm{CO}_{2}$ ) with preload set at $0.75 \mathrm{~g}$. Following recording of spontaneous contractile activity, the investigated segments were stimulated with graded doses of acetylcholine in a cumulative manner (from $10^{-10}$ to $10^{-4} \mathrm{M}$ ), washed three times with fresh buffer and finally relaxed with a single dose of isoproterenol $\left(10^{-4} \mathrm{M}\right)$. Contraction and relaxation amplitudes were measured with Chart v4.04 (ADInstrument, Australia) software and analyzed statistically (GraphPrism v 2.0, GraphPad Software, USA). Data are presented as means and their SEM.

\section{RESULTS AND DISCUSSION}

The paper presents the first description of the effect of exogenous leptin on gastrointestinal tract growth and in vitro intestinal motility of neonatal piglets. The concentration of leptin in the formula used in the present study was not measured since we do not have an appropriate assay at the moment. Nevertheless, based on human formula analyses reported by others (Houseknecht et al., 1997; SmithKirwin et al., 1998) it can be assumed that the concentration of leptin in the pig formula is small in comparison with sow colostrum and milk. The dose of leptin in the present study should be regarded as exceeding the physiological range. In the present study there were no differences in food intake between the control piglets and leptin piglets. There were also no differences in the final body weight (BW), i.e., $2.08 \pm 0.10 \mathrm{~kg}$ control vs $2.12 \pm 0.05 \mathrm{~kg}$ of leptin treated piglets. Results obtained from a study on neonatal rats fed with no suckling limits (Youan et al., 2000), however, showed that administration of leptin significantly reduced weight. The lack of differences in body weight between the control and leptin-treated piglets resulted from a similar feed intake. Since access to the milk replacer was restricted in our study, we may speculate that leptin may reduce feed intake and body weight but only from a certain level.

In our study, morphometry analysis showed no change in duodenum and jcjunum lengths, halved ileum length $(\mathrm{P}<0.001)$, reduced stomach empty weight relative to $1 \mathrm{~kg} \mathrm{BW}(\mathrm{P}<0.01)$, and reduced pancreas weight relative to $1 \mathrm{~kg} \mathrm{BW}(\mathrm{P}<0.05)$ in leptin-treated piglets as compared with the control.

In the in vitro study on isolated intestinal segments we found many clear-cut differences in motility between the leptin-supplemented and control piglets. Namely, 
the duodenum segments from the leptin piglets showed markedly higher activity than those from the control piglets, and, in contrast, the mid-jejunum segments of the leptin piglets had a smaller activity than those from the control ones. This pattern concerned both the spontaneous activity $(174 \%$ of the amplitude in the duodenum of control piglets, and $60 \%$ of the amplitude in the mid-jejunum of control piglets; Figure 1), and the pharmacologically induced activities, i.e., stimulation with acetylcholine and relaxation with isoproterenol (Figures 2 and 3 ).
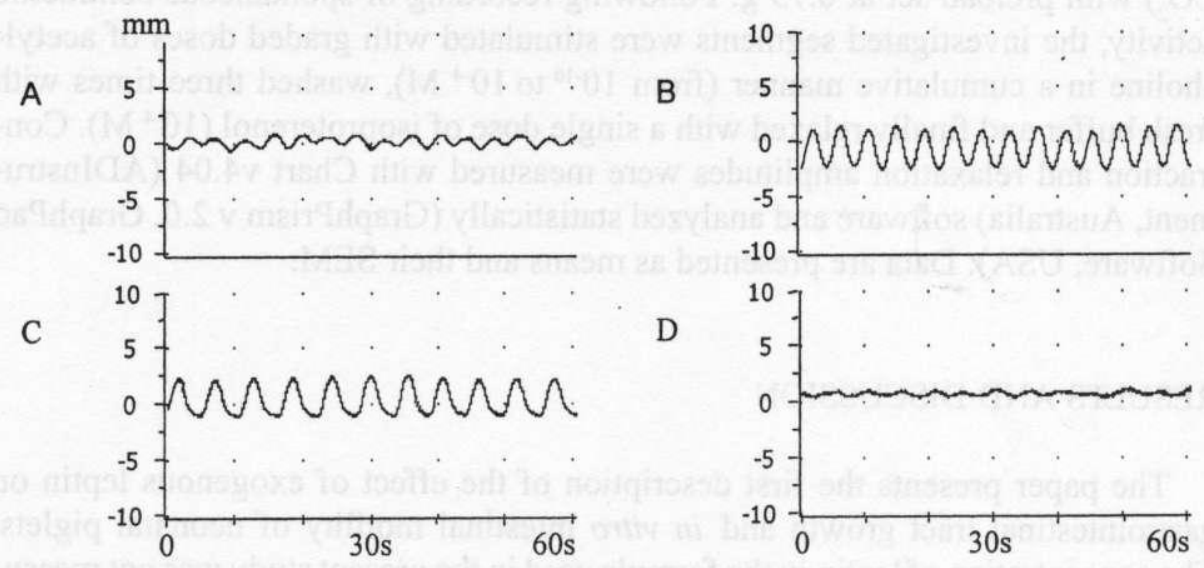

$\mathrm{D}$

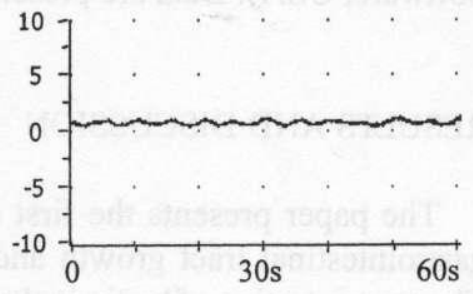

Figure 1. Representative trace of the spontaneous motor activity $(\mathrm{mm})$ of duodenum $(\mathrm{A}, \mathrm{B})$ and midintestinal (C, D) segments in vitro. Segments A and C are taken from control pig, segments B and D are taken from leptin-treated pig

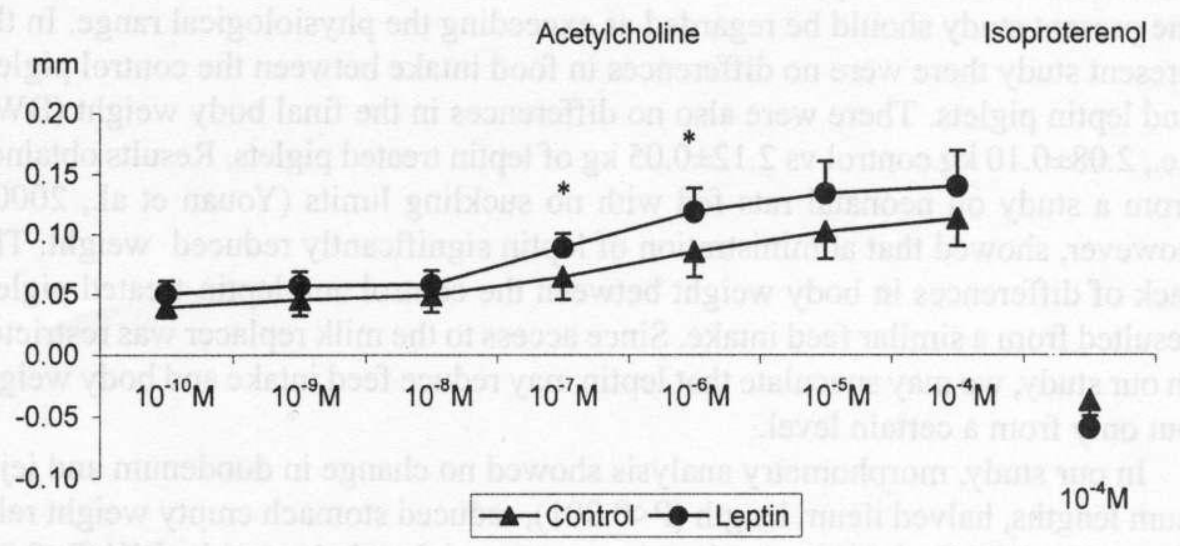

Figure 2. Mean contractile activity $(\mathrm{mm})$ of the duodenal segments from control and leptin-treated neonatal piglets in response to acetylcholine and isoproterenol. Asterisks indicate statistical difference between control and leptin pigs $\left({ }^{*} \mathrm{P}<0.05\right.$, unpaired student $t$-test) 


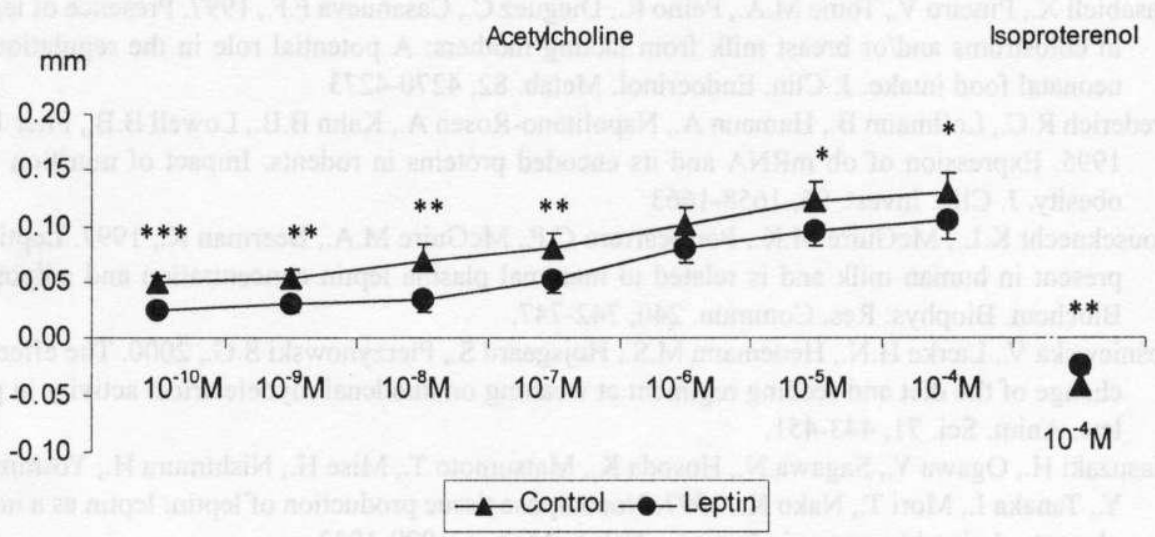

Figure 3. Mean contractile activity $(\mathrm{mm})$ of the mid-jejunum segments from control and leptintreated neonatal piglets in response to acetylcholine and isoproterenol. Asterisks indicate statistical difference between control and leptin pigs $\left({ }^{*} \mathrm{P}<0.05\right.$, ${ }^{*} * \mathrm{P}<0.01,{ }^{* * *} \mathrm{P}<0.001$, unpaired student $t$-test)

\section{CONCLUSIONS}

From the present results it can be concluded that exogenous leptin may influence gastrointestinal tract growth and the small intestine motility of neonatal piglets and that the observed stimulation of duodenal motility in concert with the inhibition of mid-intestinal motility may be of relevance in regard to gastrointestinal digesta transit. Further studies are also warranted to explore the mechanisms of leptin action since, to our knowledge, no leptin receptors have been found on the smooth muscle cells in the small intestine. The effects of leptin on local gastrointestinal blood flow and/or indirect trophic effects on the enteric nervous system and intestinal smooth muscles need to be clarified.

\section{REFERENCES}

Aoki N., Kawamura M., Matsuda T., 1999. Lactation-dependent down regulation of leptin production in mouse mammary gland. BBA - Gen. Subjects 1427, 298-306

Bado A., Levasseur S., Attoub S., Kermorgant S., Laigneau J.P., Bortoluzzi M.N., Moizo L., Lehy T., Guerre-Millo M., Le Marchand-Brustel Y., Lewin M.J., 1998. The stomach is a source of leptin. Nature 394, 790-793

Brogan R.S., Mitchell S.E., Trayhurn P., Smith M.S., 1999. Suppression of leptin during lactation: contribution of the suckling stimulus versus milk production. Endocrinology 140, 2621-2627 
Casabiell X., Pineiro V., Tome M.A., Peino R., Dieguez C., Casanueva F.F., 1997. Presence of leptin in colostrums and/or breast milk from lacting mothers: A potential role in the regulation of neonatal food intake. J. Clin. Endocrinol. Metab. 82, 4270-4273

Frederich R.C., Lollmann B., Hamann A., Napolitano-Rosen A., Kahn B.B., Lowell B.B., Flier J.S., 1995. Expression of ob mRNA and its encoded proteins in rodents. Impact of nutrition and obesity. J. Clin. Invest. 96, 1658-1663

Houseknecht K.L., McGuire M.K., Portocarrero C.P., McGuire M.A., Beerman K., 1997. Leptin is present in human milk and is related to maternal plasma leptin concentration and adiposity. Biochem. Biophys. Res. Commun. 240, 742-747.

Leśniewska V., Lærke H.N., Hedemann M.S., Højsgaard S., Pierzynowski S.G., 2000. The effect of change of the diet and feeding regiment at weaning on duodenal myoelectrical activity in piglets. Anim. Sci. 71, 443-451.

Masuzaki H., Ogawa Y., Sagawa N., Hosoda K., Matsumoto T., Mise H., Nishimura H., Yoshimasa Y., Tanaka I., Mori T., Nako K., 1997. Nonadipose tissue production of leptin: leptin as a novel placenta-derived hormone in humans. Nature Med. 3, 1029-1033

Morton N.M., Emilsson V., Liu Y.L., Cawthorne M.A., 1998. Leptin action in intestinal cells. J. Biol. Chem. 273, 26194-26201

Smith-Krwin S.M., O’Connor D.M., Johnston J., De Lancey E., Hassink S.G., Funange V.L., 1998. Leptin expression in human mammary epithelial cells and breast milk. J. Clin. Endocrinol. Metab. 83, 1810-1813

Yuan C.S., Attele A.S., Zhang L., Lynch J.P., Xie J.T., Shi Z.Q., 2000. Leptin reduces body weight gain in neonatal rats. J. Pediat. Res. 48, 380-383

Zabielski R., Naruse S., 1999. Neurohormonal regulation of the exocrine pancreas during postnatal development. In: S.G. Pierzynowski, R. Zabielski (Editors). Biology of the Pancreas in Growing Animals. Elsevier, Amsterdam, pp. 151-192

\section{STRESZCZENIE}

\section{Wpływ egzogennej leptyny na wzrost przewodu pokarmowego oraz motorykę jelita cienkiego} in vitro u nowonarodzonych prosiąt - wstępne wyniki

Osiem nowonarodzonych prosiąt podzielono losowo na dwie grupy. Wszystkie prosięta karmiono preparatem mlekozastępczym za pomocą „sztucznej maciory”. Trzy razy dziennie przez 6 dni podawano im sondą dożołądkowo roztwór fizjologiczny, $0,9 \% \mathrm{NaCl}$ (grupa kontrolna, $\mathrm{n}=5$ ) lub leptynę w ilości $10 \mu \mathrm{g} / \mathrm{kg}$ masy ciała, rozpuszczoną w roztworze fizjologicznym (grupa doświadczalna, $n=3$ ). Następnie prosięta usypiano, wyjmowano cały przewód pokarmowy, pobierano fragmenty dwunastnicy i środkowej części jelita czczego i rejestrowano ich aktywność skurczową in vitro. Mimo braku różnic w masie ciała, u prosiąt traktowanych leptyną stwierdzono różnice w masie żołądka i trzustki oraz długości jelita biodrowego w porównaniu z kontrolą. Podanie leptyny miało także istotny wpływ na aktywność skurczową jelita w sposób charakterystyczny dla poszczególnych jego odcinków $(\mathrm{P}<0,05 ; \mathrm{P}<0,01 ; \mathrm{P}<0,001$, odpowiednio). Spontaniczna aktywność skurczowa dwunastnicy, jak i jej odpowiedzi na acetylocholinę i izoproterenol, były większe w grupie prosiąt traktowanych leptyną w porównaniu z kontrolnymi, natomiast segmenty jelita czczego zachowywały się odwrotnie. Doświadczenia będą kontynuowane w celu potwierdzenia uzyskanych wyników na większej liczbie zwierząt. 